BULLETIN OF PNRPU. GEOLOGY. OIL \& GAS ENGINEERING \& MINING

ВЕСТНИК ПНИПУ. ГЕОЛОГИЯ. НЕФТЕГАЗОВОЕ И ГОРНОЕ ДЕЛО

ISSN 2224-9923

Volume/ ToM 16 №1 2017

http://vestnik.pstu.ru/geo/

УДК 550.832

Article / Статья

(C) PNRPU / ПНИПУ, 2017

\title{
DETERMINATION OF LITHOLOGIC BELONGING AND RESERVOIR PROPERTIES OF CLASTIC FORMATIONS USING FIELD GEOPHYSICAL SURVEY DATA OF BAKLANOVSKOE FIELD
}

\section{V.N. Koskov}

Perm National Research Polytechnic University (29 Komsomolskii av., Perm, 614099, Russian Federation)

\section{УСТАНОВЛЕНИЕ ЛИТОЛОГИЧЕСКОЙ ПРИНАДЛЕЖНОСТИ И КОЛЛЕКТОРСКИХ СВОЙСТВ ТЕРРИГЕННЫХ ПЛАСТОВ ПО ПРОМЫСЛОВО-ГЕОФИЗИЧЕСКИМ ДАННЫМ БАКЛАНОВСКОГО МЕСТОРОЖДЕНИЯ}

\section{В.Н. Косков}

Пермский национальный исследовательский политехнический университет (614990, Россия, г. Пермь, Комсомольский пр., 29)

Received / Получена: 15.11.2016. Аccepted / Принята: 05.03.2017. Published / Опубликована: 31.03.2017

Key words:

well logging, core, lithology, reservoir properties, fractional composition, pore space structure, regression equation, correlation relationships, systematic approach, gamma-ray log, physical properties, geological heterogeneity, histograms, radioactivity, lithologic series, formation-reservoir.

\begin{abstract}
The paper contains results of comprehensive studies of well logging data and laboratory study of the core. Studies were carried out to determine lithologic composition and reservoir properties of clastic formations of Baklanovskoe field. It is noted that grains that compose clastic rocks are diversified in size, shape, degree of roundness and sorting, granulometric and mineral composition, type and composition of cement, its structure and ratio with grains. It is stated that these features of rocks determine structure of pore space, as an ordered set of mutual relations of elements of different hierarchical levels (for example, mineral grains, samples and rock formations). It is noted that study of pore space structure, reservoir properties and lithologic features is performed based on fractional composition of rocks. However, it is impossible to understand in details entire section of even exploration and prospecting wells in case of poor core recovery. Therefore layer-by-layer description (including wells with no core) is carried out based on logging linked to results of core analysis. It was found that logs can be used for lithologic distinguishing and selection of lithologic series of clastic rocks with its material composition determination. Information about lithologic series also allows approaching to a solution for the problem of cyclic sedimentation. Equations of multiple correlations between reservoir properties of rocks and amount of psammite, silty and pelitic particles in rock matrix. It is possible to determine porosity by recorded natural radioactivity on gamma ray charts. Solving the above mentioned problems is considered on the basis of a systematic structural approach.
\end{abstract}

Изложены результаты комплексных исследований материалов геофизических исследований скважин и лабораторного изучения керна при определении литологического состава и коллекторских свойств терригенных пластов Баклановского месторождения. Отмечено, что зерна кластического материала, слагающего терригенные породы, разнообразны по своим размерам, форме, степени окатанности и отсортированности, гранулометрическому и минеральному составу, по типу и составу цемента, его строению и соотношению с зернами. Указывается, что эти особенности пород определяют структуру порового пространства как упорядоченную картину взаимных отношений элементов различных иерархических уровней (например, минеральных зерен, образцов и пластов горных пород). Отмечено, что изучение структуры порового пространства, емкостно-фильтрационных свойств и литологических особенностей осуществляется по данным о фракционном составе пород. Однако при недостаточном выносе кернового материала даже из разведочных и поисковых скважин невозможно детально представить весь разрез скважины. Поэтому послойное описание разрезов скважин (и в том числе бескерновых) осуществляется на основе геофизических исследований скважин, связанных с керновыми данными. Установлено, что по каротажным диаграммам можно проводить не только литологическое расчленение разреза, но и выделение литорядов терригенных пород с определением их вещественного состава. Сведения о литорядах позволяют также подойти к решению задачи о цикличности осадконакопления. Получены уравнения множественной корреляции между коллекторскими свойствами продуктивных пород и содержанием псаммитовых, алевритовых и пелитовых частиц в скелете породы. Показана возможность определения пористости по зафиксированным показаниям естественной радиоактивности на диаграммах гамма-каротажа. Решения вышеперечисленных задач рассмотрены на базе системно-структурного подхода.

\footnotetext{
Vladimir N. Koskov (Author ID in Scopus: 55531309800) - PhD in Geological and Mineralogical Sciences, Associate Professor at the Department of Oil and Gas Geology (tel.: +007 34221983 67, e-mail: koskov.vn@yandex.ru).
}

Косков Владимир Николаевич - кандидат геолого-минералогических наук, доцент кафедры геологии нефти и газа (тел.: +007 3422198367 , e-mail: koskov.vn@yandex.ru). 


\section{Introduction}

Study of relations between parameters that characterize any geological formation is a question of interest in oil industry. Depending on conditions of their formation and distribution, rocks have essential structural and textural features.

In section of clastic deposits rock formations are characterized by a certain set of physical properties - porosity, permeability, clayiness, water saturation, density, elasticity, specific electrical resistance, radioactivity etc.

Lithological (granulometric composition, type of cement, presence of accessory minerals) and geometric (thickness, depth, occupied area) properties of rocks also play a significant role.

These properties are studied on the basis of well geophysical and field geological studies and laboratory studies of rock samples. Each of mentioned studies characterizes individual elements of geological formations that often belong to different hierarchical levels of the geological system.

For the first time a question of systematic study of natural formations was raised in early 30's by famous biologist L. von Bertalanffy [1], who formulated the basic theses of a theory of system studies, which further development is connected to works of A.A. Liapunov, A.A. Malinovskii, D. Nidkhem, A. Rapoport, V.N. Sadovskii, Iu.A. Urmantcev, U.R. Eshbi and others. Questions of application of system approach in geology are considered in works of Iu.A. Voronin, L.F. Dementev, A.B. Kazhdan, Iu.N. Karagodin, L.D. Knoring, Iu.A. Kosygin, A.I. Kholin, I.P. Sharapov, Iu.V. Shurubor and several other researchers [2-7].

A system approach considers researchers should show that geological formation being under study can be considered as an interconnected multilevel system, and find out elements it consists of. So, for example, clastic deposits of oil and gas fields that belong to Visean age of Perm Prikamye are presented mainly by sandstones, siltstones and mudstones. The grains of clastic material composing these rocks are diverse in its size, shape, degree of roundness and sorting, granulometric and mineral composition. In addition, sand-clayish rocks also differ in composition and type of cement, its structure and ratio with grains. All these features of rocks determine structure of pore space, which represent position of elements in space order (for example, grains, mineral particles in rock matrix), of an integral geological formation (sample, layer) associated with nature of these properties. It should be noted that if granulometric composition is a characteristic of rock structure, then for a structure of pore space of clastic reservoirs such a characteristic is volume of interconnected pores and pore channels.

When determining its structure a geological formation itself should be considered as a natural system consisting of elementary parts. The total of system elements allows determination geometry of void space of rocks. Structural relations are important only in context where they characterize stability of a system. Therefore, a different combination of structural characteristics of rocks determines a degree of stability of a system and its heterogeneity [8-11].

So, due to cementation of particles, pore channels narrow down and even their closure, which often leads to formation of dead-end zones. All this complicates a structure of pore space of rocks. Distribution of grains in rock volume and their granulometric coefficients influence formation of void space strongly [3, 12-15].

The relationship between structure of rock matrix and structure of pore space is most clearly presented on example of stacking and cementation of particles. Heterogeneity of production formations (as a degree of stability of geological formation system) cause a difference in their reservoir properties.

Reservoir properties (porosity, permeability, oil saturation, clayiness, residual water content) of individual reservoirs and fields, belonging even to the same tectonic structure, of the same origin and sedimentation conditions have significant differences.

It should be noted that there are certain regularities between mentioned reservoir parameters that represent properties of geological formation at higher level of hierarchy (sample, formation), which is logically related to characteristics of a formation at lower (structural) level (grains, pores) [3, 5].

To describe structural features of geological formations of lower level it is needed to use 
coefficients of granulometric studies that are as follows: average grain size (median diameter $M d$ ), coefficient of asymmetry $K s$ and coefficient of heterogeneity $S$. These coefficients reflect the main features and nature of distribution of grains as a building material involved in formation of rock and void space $[3,16]$.

In turn, variability of production reservoir parameters and degree of their geological heterogeneity (i.e. macrostructure of pore space) as properties of geological objects at a higher structural level can be characterized by coefficients of sandiness $k_{\text {sand, }}$ stratification factor $k_{\text {strat }}$, connectedness $k_{\text {con }}$, effect $k_{e}$ etc. [3].

Fractional composition is one of the main characteristics of clastic rocks. A structure of pore space and thus reservoir properties and lithological features of rocks depend on it. Fractional composition is determined by core samples in laboratory conditions. However, core material is usually not enough to represent in detail entire well section. It characterizes individual intervals of well section only [10, 17]. Therefore, conventional formation of layer-by-layer description of well section is carried out on the basis of continuous displaying of well section by well logging diagrams associated with core data. As is known, when describing a core, a lot of lithological differences of rocks are recorded, which cannot be identified by well logging curves. Only rocks with sharply outlined lithological and physical properties such as clay rocks, siltstones, sandstones etc., i.e. such groups (lithological series), which combine similar in material composition and physical properties of rocks variety can be distinguished by logs. Usually, laboratory description of core of clastic deposits is based on results of granulometric and instrumental analysis of thin sections.

\section{Determination of lithology and reservoir properties of rocks based on results of core treatment}

Most often lithological and structural properties of clastic rocks are determined from granulometric composition data, nature of its packaging, content and composition of cement in rock matrix. Reservoir properties are determined by gas saturation and flow method.
Thus, open porosity of clastic rocks of Visean age of Baklanovskoe field varies from 2.7 to $27.8 \%$. A section of this field is represented mainly by sandstones, silty sandstones, silt and clay rocks. Carbonate rocks (limestones of varying degree of dolomitization) play a subordinate role in a roof of Tula layer.

Sandstones are quartz, light gray and gray, poorly cemented, with carbonaceous inclusions, carbonized plant remains and inclusions of pyrite. Sandstones are heterogeneous, with various sorting and rounding of mineral grains. Content of pelite fraction $\mathrm{C}_{\mathrm{Pl}}$ (smaller than $0.01 \mathrm{~mm}$ ) vary from 3.3 to $14.4 \%$. A prevalence of psammitic fraction of $\mathrm{C}_{\mathrm{Ps}}$ with a particle size of $0.25-0.1 \mathrm{~mm}$ in sandstones is 47-82 \%. The content of coarse-grained fraction (more than $0.5 \mathrm{~mm}$ ) does not exceed $0.3 \%$. Fractions with size of $0.5-0.25 \mathrm{~mm}$ rare make up $10 \%$. Content of siltstone fraction of $\mathrm{C}_{\mathrm{Al}}$ (0.1-0.01 mm) varies from 9.4 to $23.2 \%$. Cement in sandstones is more often clayish and carbonaceousclayish, less often calcite, carbonate and mixed. Sometimes cementation of rock matrix is done due to consolidation of grains.

Siltstones have different grain size. They are quartz, gray, light and dark gray, carbonaceous and carbonaceous-argillaceous, layered. Siltstones are composed of detrital material, usually have worse roundness than sandstones. Content of carbonate cement $\mathrm{C}_{\mathrm{C}}$ in rock matrix (as in sandstones and silty sandstones) is usually small. In general, the silt fraction predominates (up to $66 \%$ ), content of fractions with particle size of $0.25-0.1 \mathrm{~mm}$ is $22-23 \%$.

Silty sandstones can be found in section rarely. According to granulometry data they occupy an intermediate position between sandstones and siltstones (Table 1, Fig. 1). It is indicative that silty sandstones have the same content of psammitic and silty fractions ( $42-47 \%$ each).

The argillites are predominantly dark gray, almost black, unevenly silt and carbonaceous, thinlayered and slate. Content of $\mathrm{C}_{\mathrm{Pl}}$ is more than $50 \%$, content of $\mathrm{C}_{\mathrm{Al}}$ is about $40 \%$.

Sandstones, silty sandstones and siltstones refer to oil-bearing rocks (see Table 1). In terms of gas permeability they are divided into four classes: I unproductive reservoirs $\left(K_{\text {perm }}<1 \mathrm{mD}\right)$, II - lowproductive $\left(K_{\text {perm }}=1-10 \mathrm{mD}\right)$, III - mediumproductive $\left(K_{\text {perm }}=10-160 \mathrm{mD}\right)$, IV - highly productive $\left(K_{\text {perm }}>160 \mathrm{mD}\right)$. 
Table 1

Characterization of oil-bearing rocks by permeability and granulometric composition

\begin{tabular}{|c|c|c|c|c|c|c|c|}
\hline \multirow{3}{*}{ Oil-bearing rock } & \multirow{3}{*}{$K_{\text {perm }}, \mathrm{mD}$} & \multicolumn{6}{|c|}{ Granulometric composition, $\%$} \\
\hline & & \multicolumn{3}{|c|}{ psammites } & \multirow{2}{*}{$\begin{array}{c}\text { silt } \\
0,1-0,01 \mathrm{~mm}\end{array}$} & \multirow{2}{*}{$\begin{array}{c}\text { pelites } \\
<0,01 \mathrm{~mm} \\
\end{array}$} & \multirow{2}{*}{$\begin{array}{c}\text { carbonate } \\
\text { particle }\end{array}$} \\
\hline & & $>0,5 \mathrm{~mm}$ & $0,5-0,25 \mathrm{~mm}$ & $0,25-0,1 \mathrm{~mm}$ & & & \\
\hline \multirow{4}{*}{ Sandstones } & $<1$ & 0,16 & 13,81 & 47,03 & 18,28 & 14,40 & 6,32 \\
\hline & $1-10$ & 0,21 & 4,04 & 57,33 & 23,11 & 12,86 & 2,45 \\
\hline & $10-160$ & 0,07 & 3,27 & 64,93 & 23,18 & 7,78 & 0,77 \\
\hline & $>160$ & 0,24 & 4,73 & 82,23 & 9,37 & 3,26 & 0,17 \\
\hline \multirow{4}{*}{ Silty sandstones } & $<1$ & 0,07 & 0,43 & 42,33 & 43,00 & 14,17 & - \\
\hline & $1-10$ & 0,03 & 0,50 & 43,73 & 44,17 & 11,60 & - \\
\hline & $10-160$ & 0,08 & 1,52 & 44,84 & 46,50 & 6,28 & 0,78 \\
\hline & $>160$ & 0.10 & 1,86 & 45,90 & 47,00 & 5,00 & 0,14 \\
\hline \multirow{4}{*}{ Siltstones } & $<1$ & 0,14 & 1,09 & 22,47 & 59,70 & 13,69 & 2,91 \\
\hline & $1-10$ & 0,09 & 0,95 & 23,36 & 61,40 & 12,81 & 1,39 \\
\hline & $10-160$ & 0,12 & 1,07 & 23,23 & 65,99 & 8,00 & 0,96 \\
\hline & $>160$ & - & 1,02 & 31,35 & 56,50 & 10,48 & 0,65 \\
\hline
\end{tabular}
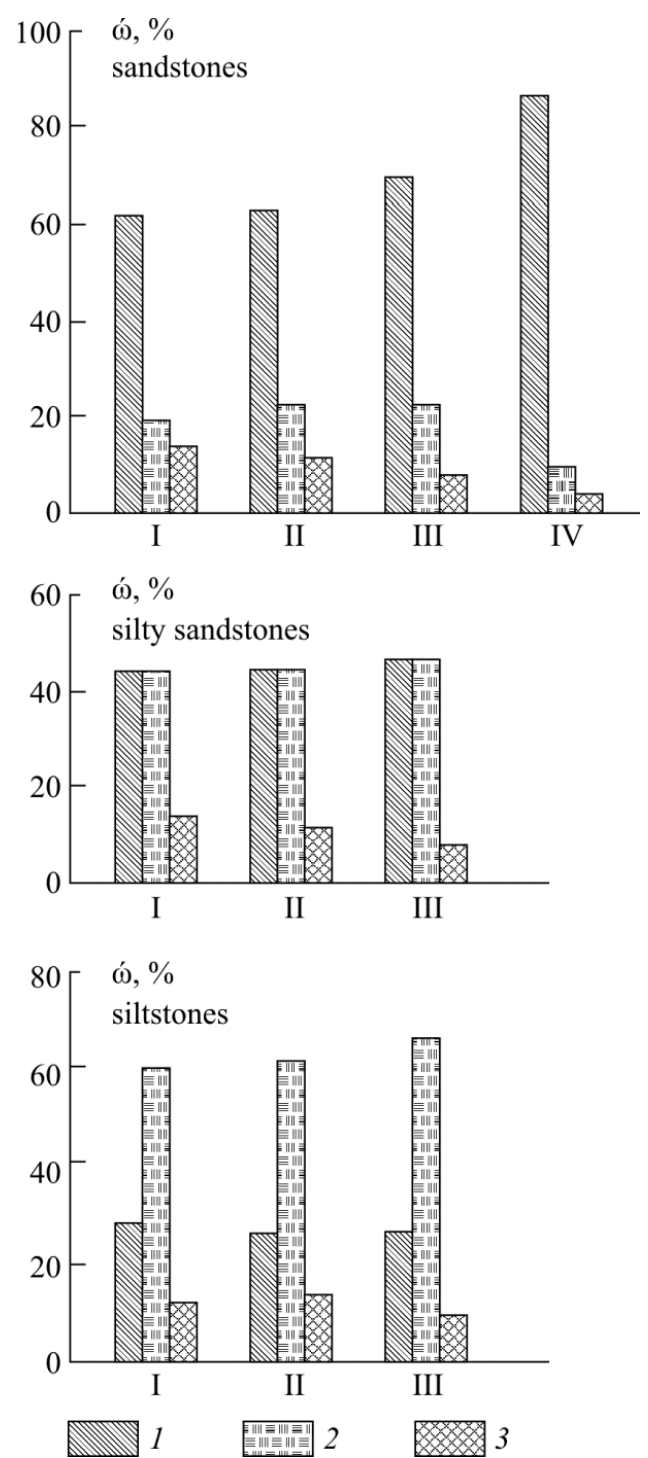

Fig. 1. Histograms of fractional composition of Tula clastic deposits of Baklanovskoe field: $\dot{\omega}$ - fraction content, $\% ; 1-$ sandstones,

2 - silty sandstones, 3 - siltstones; $\mathrm{I}<1 \mathrm{mD}$; II - 1-0 mD; III - 10-160 mD; IV > $160 \mathrm{mD}$
Analysis of the data of Table 1 and Fig. 1, 2 shows that content of pelitic and psammitic fractions has the greatest and decisive influence on flow properties of rocks (permeability). The same effect have these fractions on volume capacity (porosity).

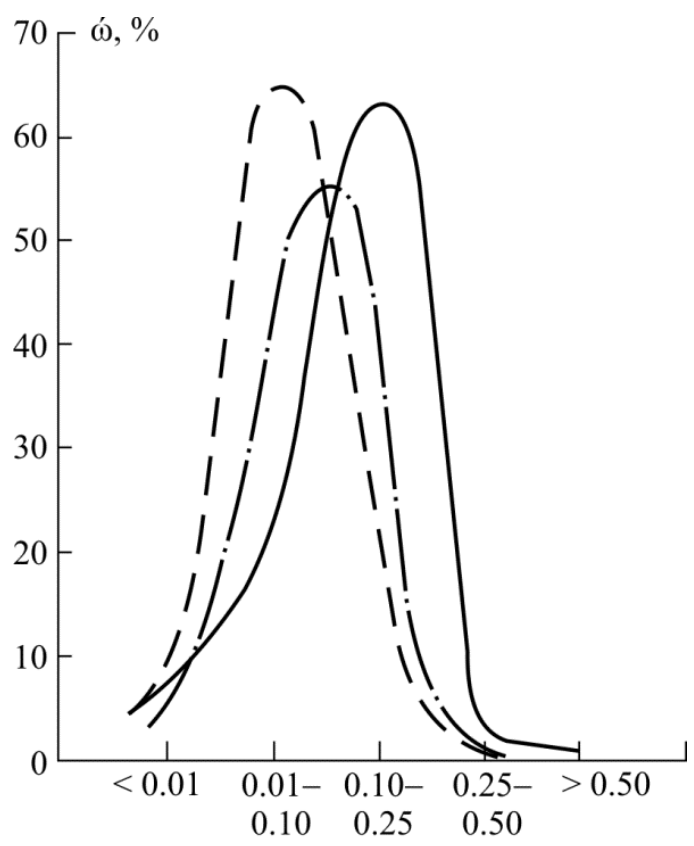

Fraction size, $\mathrm{mm}$

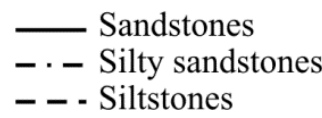

Fig. 2. Fractional composition distribution curves in different groups of rocks in class of medium-productive reservoirs $\left(K_{\text {perm }}=10-160 \mathrm{mD}\right)$

Content of carbonate material for different classes of reservoirs in terms of permeability vary spontaneously and unsystematicly and does not always correspond to certain lithological variety of clastic rocks. 
This fact is confirmed by equations of multiple correlation between coefficients of porosity and permeability and content of psammitic, silty, pelitic fractions and content of carbonate particles for clastic reservoirs of Baklanovskoe field:

$$
\begin{gathered}
K_{p}=0.45 \mathrm{C}_{\mathrm{Ps}}+0.4 \mathrm{C}_{\mathrm{Al}}+0.19 \mathrm{C}_{\mathrm{Pl}}-24.6, \\
K_{\text {perm }}=8.93 \mathrm{C}_{\mathrm{Ps}}-20.71 \mathrm{C}_{\mathrm{Pl}}+70.35
\end{gathered}
$$

where $K_{p}$ and $\mathrm{C}, \%, K_{\text {perm }}, \mathrm{mD}$.

The equation (1) shows the capacitive properties of reservoirs are estimated by content of all fractions. Flow properties are determined mainly by values of pelite fraction (2), i.e. in fact, according to content of clay particles in matrix of rock. Insignificant content of carbonate particles does not have a noticeable effect on reservoir properties, which is confirmed by absence of correlation with $\mathrm{C}_{\mathrm{C}}$ values in both equations.

It should be noted that in addition to using results of granulometric analysis of core to determine porosity and permeability in laboratory conditions, it is compulsory to study irreducible water saturation of rocks. It is known that in reservoir conditions productive rocks contain a certain amount of irreducible water. Irreducible water saturation of clastic rocks is usually determined by indirect laboratory methods such as capillary pressure and centrifugation.

It was found, for example, that irreducible water saturation of $K_{i . w}$ of clastic reservoirs of Lower Carboniferous of Baklanovskoe field varies widely, in particular from 16 to $57 \%$ for sandstones and from 28 to $96 \%$ for siltstones. According to these data, siltstones contain irreducible water in much larger quantities than sandstones.

While considering $K_{i . w}=f\left(K_{p}\right)$ и $K_{i . w}=f\left(\lg K_{\text {perm }}\right)$ there is a strong trend of irreducible water amount to decrease with increase of porosity and permeability (Fig. 3, $a, b$ ).

Regression equation $K_{i . w}=f\left(K_{p}\right)$ is characterized by a high density of relationships between compared parameters correlation coefficient $r=0.76$ ) and has following analytical equation:

$$
K_{i . w}=114.8-0.56 K_{p}^{2}+1.5 \cdot 10^{-2} K_{p}^{3} .
$$

There is even higher dependency between irreducible water saturation and permeability $(r=0.87)$ :

$$
K_{i . w}=95.03-52.3 \lg K_{\text {perm }}+7.67\left(\lg K_{\text {perm }}\right)^{2} .
$$
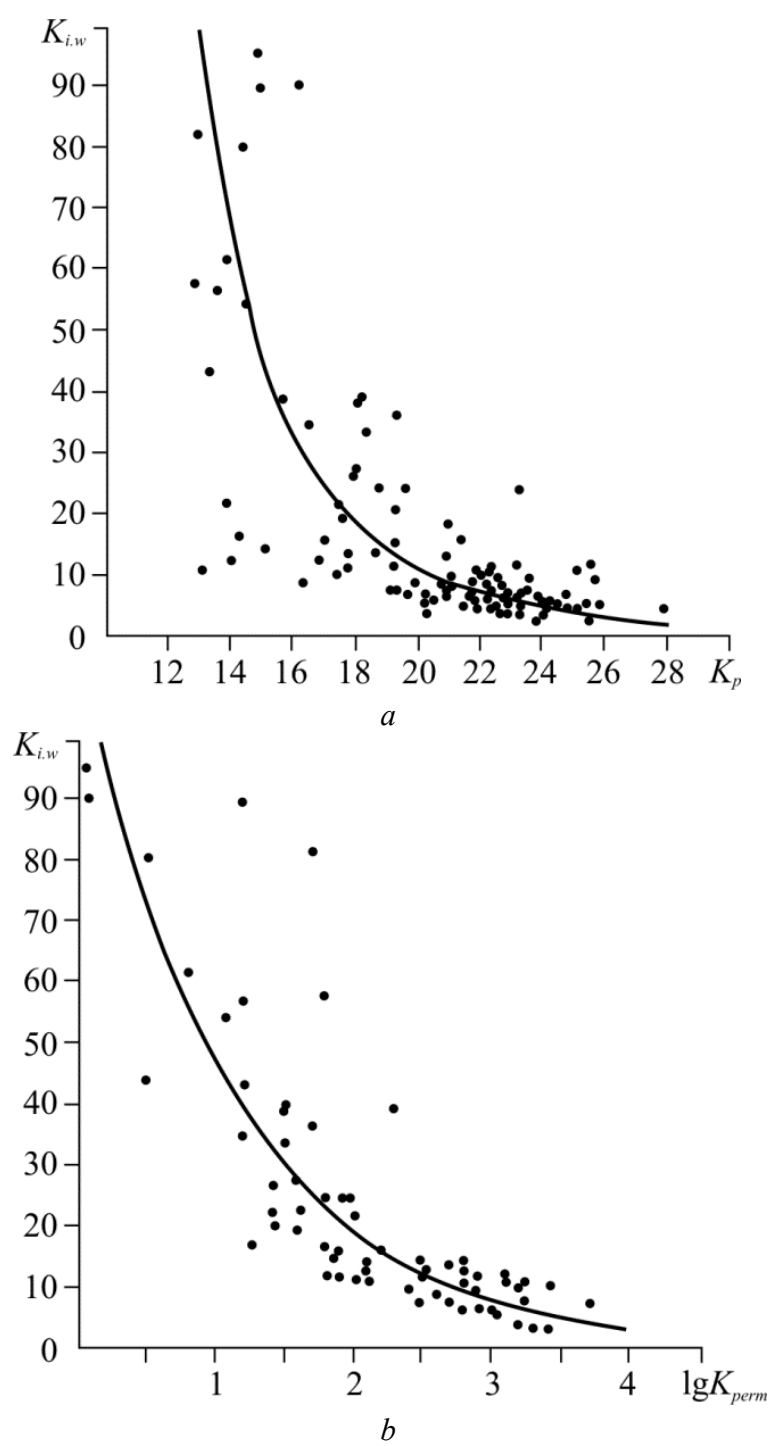

Fig. 3. A function of irreducible water saturation of clastic reservoirs from: $a-K_{p} ; b-\lg K_{\text {perm }}$

According to results of laboratory studies, it is established that reservoirs with porosity of less than $14 \%$ contain more than $70 \%$ of irreducible water.

$$
K_{i . w}=114.8-0.56 K_{p}^{2}+1.5 \cdot 10^{-2} K_{p}^{3} .
$$

An even closer relationship is observed between irreducible water saturation and permeability $(r=0.87)$ :

$$
K_{i . w}=95.03-52.3 \lg K_{\text {perm }}+7.67\left(\lg K_{\text {perm }}\right)^{2} .
$$

According to results of laboratory studies, it was established that productive rocks with porosity of less than $14 \%$ contain more than $70 \%$ of irreducible water.

The highest value of irreducible water saturation is caused by high content of clay 
particles in cement of rock, which, in turn, are capable of retaining water in significant quantities due to their large adsorption surface. Between irreducible water saturation $K_{i, w}$ and clayiness $K_{\text {clav }}$, there is a rectilinear dependence with a high correlation coefficient $(r=0.89)$ :

$$
K_{i . w}=4.05 K_{\text {clay }}-2.85 \text {. }
$$

\section{Determination of lithological composition and reservoir properties of rocks according to well logging}

For complete characterization of clastic rocks by content of fractions gamma-ray (GR) logging method is promising. GR-method registers natural radioactivity of rocks, caused mainly by content of thorium ( $\mathrm{Th}$ ), radium ( $\mathrm{Ra})$ and radioactive potassium isotope $\left(\mathrm{K}^{40}\right)$ in it [18].

Study of spectral composition of natural gamma radiation of reservoirs represented by quartz sandstones in oil fields in Perm region made it possible to reveal patterns of distribution of radioactive elements ( $\mathrm{Th}, \mathrm{Ra}, \mathrm{K}^{40}$ ) depending on granulometric composition of rocks. It was found that total content of radioactive elements relative to pelitic, psammitic and silty fractions is characterized by high tightness of bond, but their character for each fraction is different. This indicates a possibility of establishing dependencies between different fractions and GR readings.

Based on numerous studies, it was established that application of well logging methods, such as potential of spontaneous polarization (PS) and GR, is legitimate during determination of reservoir properties in clastic reservoirs [8, 11, 19-21].

In our particular case, the most informative method for determining permeability in clastic reservoirs is GR method. Application of PS method is limited due to weak differentiation of PS curve in wells drilled in salt drilling fluids. Wells with good quality of recorded PS are very few.

As is known, GR is used to study geological sections of wells and is based on differentiation (separation) of rocks from their natural $\gamma$-activity. The essence of GR is to study natural gamma field along a wellbore by recording intensity of radiation that occurs during spontaneous decay of radioactive elements in rocks $[10,19,22]$. GeigerMuller or more efficient scintillation counters are used as an indicator for section determination. Obtained during measurement curve characterizes intensity of gamma radiation of formations along a wellbore is called gamma-ray logging curve.

Natural radioactivity of rocks is caused mainly by presence of natural radioactive elements uranium $U$ and its decay products, radium $\mathrm{Ra}$, thorium $\mathrm{Th}$ and radioactive isotope of potassium ${ }^{40} \mathrm{~K}$. Remaining radioactive elements such as rubidium, samarium, lanthanum, lutetium etc. do not make a significant contribution to total natural radioactivity of rocks.

Radioactivity of sedimentary rocks (a subject of our research) is directly dependent on degree of their clay content. Clay sandstones and siltstones are characterized by intermediate values of radioactivity i.e. between radioactivity of pure rocks (e.g. clean sandstones) and radioactivity of clay rocks. Enrichment of sedimentary rocks with radioactive elements occurs due to their precipitation or adsorption by finely dispersed and colloidal particles. Therefore, due to large specific surface, clay rocks (clays, argillites, clay siltstones) sorb a large number of radioactive elements during sedimentation process and are characterized by increased indications in GR diagrams. Besides, a possibility of extensive use of GR method for determining reservoir properties of rocks is that the GR method represents certain extent geometry of void space and reveals stable relationship with fractional composition of rocks, since the structure of pore space of clastic rocks is directly related to reservoir properties. It should be noted that radioactivity of carbonate rocks is usually 1.5-2.0 times lower than that of sandy clay rocks $[19,22]$.

Study of cliff section is of particular interest, since clay parameter determines reservoir properties of rocks, in particular their porosity and permeability $[8,9,23]$.

So, natural radioactivity of rocks basically depends on mineral composition and cement of rocks. Registered radiation $J_{\gamma}^{\text {res }}$ in front of formation is sum of emissions of a formation, washing liquid and background of device. In general, intensity of natural radioactivity detected by wellbore radiometer (GR method) is directly proportional to radioactivity of rocks traversed by a well $[9,10,19]$.

Since magnitude of radioactivity of sedimentary rocks correlates well with their clay content, it is possible to pick formations with different content of clay in rock matrix in clastic section on GR diagrams. Configurations 
of GR curves during logging are usually distorted due to presence of an integrating cell, which causes inertia of apparatus [24]. Therefore, GR diagrams appear asymmetric with respect to middle of formation and shifted in direction of movement of device. Boundaries of reservoir (with reduced radioactivity) are determined from points corresponding to onset of decay of GR curve in base of formation and beginning to rise at its roof [25].

On the one hand the basis of a method for determining porosity by GR is correlation between porosity of clastic rocks and clayiness of $K_{p}=f\left(\mathrm{C}_{\text {clay }}\right)$, on the other hand between clayiness and natural radioactivity of the rocks, $\Delta I_{\gamma}=f\left(\mathrm{C}_{\text {clay }}\right)$.

GR-curves registred in wells with different measurement conditions and radiometric equipment features are not comparable in their quantitative interpretation. In order to exclude influence of a source of neutrons in NGR channel, design features of measuring equipment, background and well conditions on GR values relative values of gamma activity of reservoir (double difference parameter $\Delta J_{\gamma}$ ) (Fig. 4) is used. Usually, reference formations are dense limestones of Tornaisian stage with minimum GR values $\left(J_{\gamma \text { min }}\right)$ and clays of Tula layer with maximum GR values $\left(J_{\gamma \max }\right)[10]$.

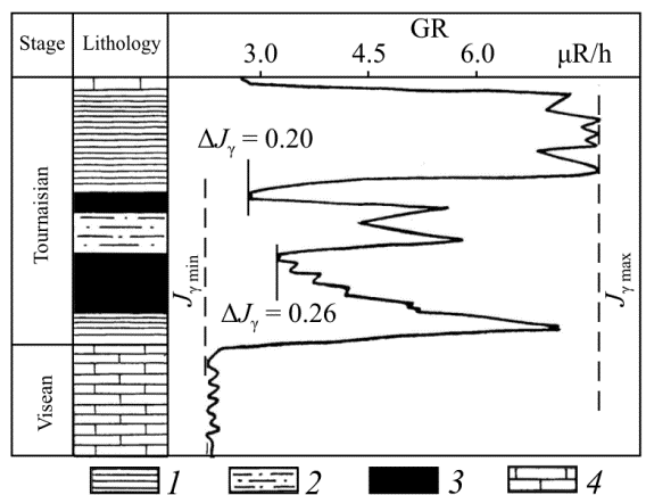

Fig. 4. Calculation of $\Delta J_{\gamma}$ by GR: 1 - clay; 2 - siltstones; 3 - reservoir; 4 - limestone

Parameter $\Delta J_{\gamma}$ is calculated by equation

$$
\Delta J_{\gamma}=\frac{\left(J_{\gamma}^{\text {res }}-J_{\gamma \min }\right) \pm \delta J_{\gamma}}{J_{\gamma \max }-J_{\gamma \text { min }}},
$$

where $J_{\gamma}{ }^{\text {res }}-$ value of GR in front of a reservoir; $J_{\gamma \text { max }}$ - maximum value of GR in front of clays; $J_{\gamma}$ min - minimum value of GR in front of tight limestones; $\delta J_{\gamma}$ - correction that consider changes in recorded intensity of gamma ray as a function of speed of movement of tool $V$, constant of time of integrating cell $\Delta t$ and formation thickness $h$. Corrections are introduced for low thickness formations according to an equation $h \geq 4 V t / 3600$.

In order to determine $K_{p}$ from GR for studied field a function $\Delta J_{\gamma}=f\left(K_{p}\right)$ is used. For instance, established dependence for clastic reservoirs of Baklanovskoe field is characterized by a high correlation coefficient $(r=0.92)$ and has following analytical equation:

$$
K_{p}=-69.7 \Delta J_{\gamma}^{3}+96.3 \Delta J_{\gamma}^{2}-63.9 \Delta J_{\gamma}+25.2 \text {. (9) }
$$

Together with other methods of well logging GR data is also used for definition of lithologic well section and its correlation, for definition of reservoirs and its clayness evaluation. Under favorable conditions GR materials are used for indirect determination of porosity, irreducible water saturation and permeability of reservoir rocks $[8,10]$.

GR records (parameter $\Delta J_{\gamma}$ ) can also be used for express determination of clastic rock lithologic sequences for a specific field. As an example, double difference parameter $\Delta J_{\gamma}$ as a function of fraction content were built and analyzed for Baklanovskoe field (Fig. 5).

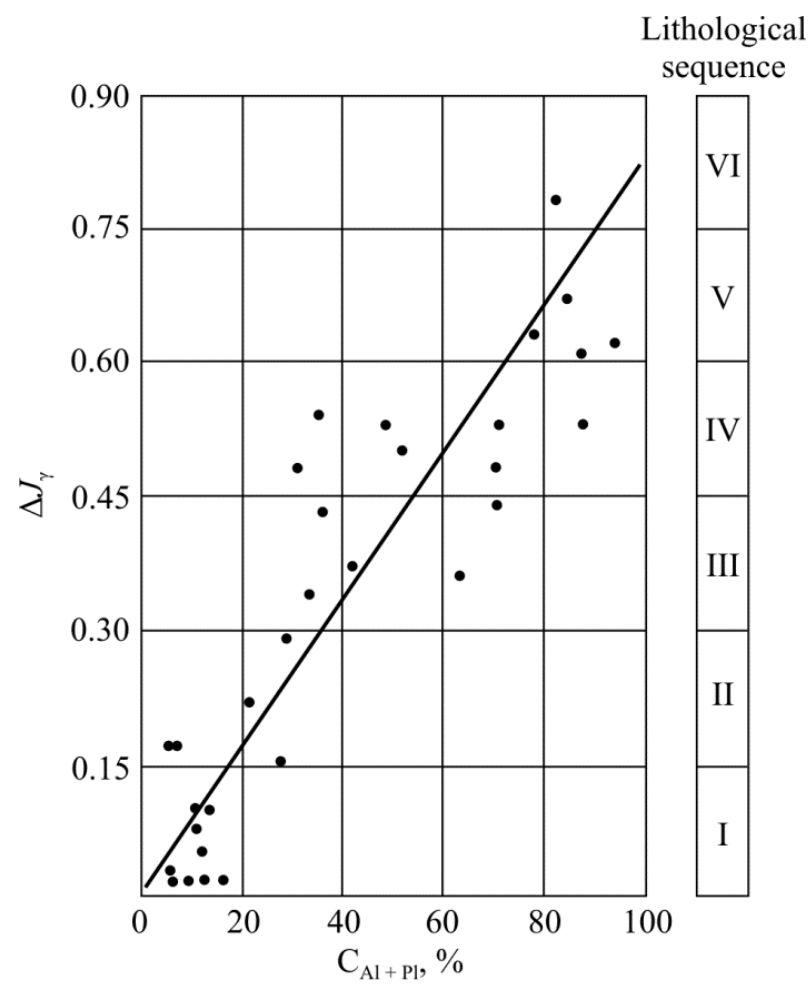

Fig. 5. Function $\Delta J \gamma=f\left(\mathrm{C}_{\mathrm{Pl}+\mathrm{Al}}\right)$ and lithological sequences of rocks 
The most tight relation (correlation coefficient $r=0.91$ ) belongs to function of total saturation of pelite and silt $\Delta J_{\gamma}=f\left(\mathrm{C}_{\mathrm{Pl}}+\mathrm{Al}\right)$. The equation of regression is as follows:

$$
\Delta J_{\gamma}=8.2 \cdot 10^{-3} \mathrm{C}_{\mathrm{Pl}+\mathrm{Al}}+0.01 \text {. }
$$

It was found that content of clay particles for each core sample is about one-third of total content of silt and clay particles. This fact allows giving a fairly real description of lithologic sequences of clastic rocks that occur in sections of wells. All clastic rocks were divided into six lithologic sequences: three in oil-bearing intervals and the same in enclosing rocks (non-reservoirs). An interval with $\Delta J_{\gamma}$ equal to 0.15 was chosen as a basis. Such choice is conditioned by the fact that among oil-bearing formation traditionally there are three groups of reservoirs with low, medium and high reservoir properties. Herewith lower limit of porosity $\Delta J_{\gamma}$ is 0.45 . According to chosen interval of $\Delta J_{\gamma}$ values lithologic sequences were picked up even in non-oil-bearing part of well section (Table 2).

Table 2

Characteristics of lithologic sequences, picked up from GR diagrams

\begin{tabular}{|c|c|c|c|c|l|c|}
\hline \multirow{2}{*}{$\begin{array}{l}\text { Lithologic } \\
\text { sequences }\end{array}$} & \multirow{2}{*}{$\begin{array}{c}\text { Interval average } \\
\text { porosity, } \%\end{array}$} & \multicolumn{3}{|c|}{$\begin{array}{c}\text { Interval average } \\
\text { fraction content, } \%\end{array}$} & \multirow{2}{*}{$\begin{array}{c}\Delta \\
\text { Content of lithologic sequence }\end{array}$} & fractions \\
\cline { 3 - 5 } & & $\mathrm{Ps}$ & $\mathrm{Al}$ & $\mathrm{Pl}$ & & $<0.15$ \\
\hline I & 22.1 & 92.1 & 5.3 & 2.6 & Clean sandstone, silty sandstone & $0.15-0.30$ \\
\hline II & 16.5 & 73.7 & 17.6 & 8.7 & Silty sandstone, sand silt, sandy siltstone & $0.30-0.45$ \\
\hline III & 12.5 & 55.3 & 30.0 & 14.7 & Siltstone-clayish sandstone, siltstone & $0.45-0.60$ \\
\hline IV & 10.4 & 37.0 & 42.2 & 20.8 & Clayish sandstone, clayish-sandy siltstone & $0.60-0.75$ \\
\hline V & - & 17.3 & 55.5 & 27.5 & Clayish siltstone, sandy mudstone & $>0.75$ \\
\hline VI & - & $<8.0$ & 62.0 & 30.0 & Very clayish siltstone, clay rocks, mudstone & \\
\hline
\end{tabular}

\section{Conclusion}

Results of conducted studies on core of Baklanovskoe field allow to differentiate structure of pore space of reservoirs on basis of fractional composition data of rock samples. A close relationship between reservoir properties of oilbearing rocks and content of psammite, silty and pelitic fractions is observed.

Oil-bearing rocks are characterized in terms of permeability and granulometric composition. Reliability of received information is confirmed by equations of multiple correlation with high correlation coefficients. It is shown that there is a clear tendency of irreducible water saturation to decrease with increase in reservoir properties of formation.

It is found that GR logging is the most promising method among spectral methods of core analysis allowing both to determine porosity of oil-bearing formations in wells with no core and pick up lithological sequences in oil-bearing and non-oilbearing areas of well section. It helps to reveal complete lithological and structure characteristics of rocks.

\section{References}

1. Bertalanfi L. von. Allgemeine Systemtheorie. Wege zu einer neuen mathesis universalis, 1957, vol. 12, no. 5/6, pp. 8-12.

2. Gudkov E.P., Koskov V.N. Sistemno-strukturnoe modelirovanie neftegazovykh zalezhei po dannym promyslovo-geofizicheskikh issledovanii [Systemstructural modeling of oil and gas deposits based on field geophysical surveys]. Geologiia, geofizika $i$ razrabotka neftianykh i gazovykh mestorozhdenii, 1997, no. 12, pp. 21-24.

3. Dement'ev L.F. Sistemnye issledovaniia v neftegazopromyslovoi geologii [System studies in oil and gas field geology]. Moscow, Nedra, 1988, 204 p.

4. Knoring L.D. Osnovy teorii optimizatsii razvedki neftianykh mestorozhdenii [Fundamentals in optimization of oilfield exploration theory]. Leningrad, Nedra, 1980, 304 p.
5. Koskov V.N. Interpretatsiia dannykh GIS na baze sistemno-strukturnogo podkhoda [Interpretation of well logging data on the basis of system-structural approach]. Perm': Izdatel'stvo Permskogo natsional'nogo issledovatel'skogo politekhnicheskogo universiteta, 2012, $140 \mathrm{p}$.

6. Shurubor Iu.V. Sistemno-strukturnoe modelirovanie razrabotki neftianykh i gazovykh mestorozhdenii (kontseptual'nye osnovy; balansnye, statisticheskie i balansno-statisticheskie metody, ikh algoritmicheskoe i programmnoe obespechenie) [System-structural modeling of development of oil and gas fields (conceptual bases, balance, statistical and balance-statistical methods, its algorithmic and software support)]. Perm', Permskii politekhnicheskii institut, 1991, $42 \mathrm{p}$.

7. Urmantsev Yu.A. Symmetry of system and symmetry. Computers \& Mathematics with Applications, 
1986, vol. 12, iss. 1-2, part B, pp. 379-405. DOI: 10.1016/0898-1221(86)90160-4

8. Vendel'shtein B.Iu., Rezvanov R.A. Geofizicheskie metody opredeleniia parametrov neftegazonosnykh kollektorov [Geophysical methods for determining parameters of oil and gas reservoirs]. Moscow, Nedra, 1978, $318 \mathrm{p}$.

9. Vendel'shtein B.Iu., Zoloeva G.M., Tsareva N.V. et al. Geofizicheskie metody izucheniia podschetnykh parametrov pri opredelenii zapasov nefti i gaza [Geophysical methods of studying evaluation parameters in determination of oil and gas reserves]. Moscow, Nedra, 1985, $248 \mathrm{p}$

10. Koskov V.N., Koskov B.V. Geofizicheskie issledovaniia skvazhin i interpretatsiia dannykh GIS [Well logging and its interpretation]. Perm', Izdatel'stvo Permskogo gosudarstvennogo tekhnicheskogo universiteta, 2007, 317 p.

11. Gorbachev Iu.I. Geofizicheskie issledovaniia skvazhin [Well logging]. Moscow, Nedra, 1990, 398 p.

12. Khanin A.A. Petrofizika neftianykh i gazovykh plastov [Petrophysics of oil and gas reservoirs]. Moscow, Nedra, 295 p.

13. Griffiths I. Grain-size distribution and reservoirrock characteristics. Bulletin of the American Association of Petroleum Geologists, 1952, vol.36, no.2, pp.205-229.

14. Pirson S.J. Handbook of well log analysis: for oil \& gas formation evaluation. Prentice-hall, INK, Englewood Cliffs, N.J., 1963, 414 p.

15. Tickell F.A., Hiatt W.N. Effect of angularity of grain on porosity and permeability of unconsolidated sands. Bulletin of the American Association of Petroleum Geologists, 1938, vol. 22, no.9, pp.1272-1274.

16. Dement'ev L.F., Akbashev F.S., Fainshtein V.M. Izuchenie svoistv neodnorodnykh terrigennykh neftenosnykh plastov [Study of properties of heterogeneous clastic oil-bearing formations]. Moscow, Nedra, 1980, 213 p.

17. Stasenkov V.V., Zhdanov A.S. Kompleksnoe ispol'zovanie geologo-geofizicheskikh metodov vydeleniia neftegazoproduktivnykh kollektorov [Integral use of geological and geophysical methods for allocation of oil and gas reservoirs]. Moscow, Vserossiiskii nauchnoissledovatel'skii institut organizatsii, upravleniia i ekonomiki neftegazovoi promyshlennosti, 1976, $56 \mathrm{p}$.

18. Gusev V.M., Koskov V.N., Nekrasov A.S. Otsenka granulometricheskogo sostava kvartsevykh peschanikov po dannym gamma-metoda [Evaluation of granulometric composition of quartz sandstones according to gamma method]. Napravleniia $i$ metodika poiskovorazvedochnykh rabot $v$ Permskom Prikam'e. Moscow, Institut geologii i razrabotki goriuchikh iskopaemykh, 1984, pp.86-90.

19. Pomerants L.I., Bondarenko M.T., Gulin Iu.A., Koziar V.F. Geofizicheskie metody issledovaniia neftianykh i gazovykh skvazhin [Geophysical methods of oil and gas wells survey]. Moscow, Nedra, 1981, 376 p.

20. Itenberg S.S., Dakhkil'gov T.D. Geofizicheskie issledovaniia $\mathrm{V}$ skvazhinakh [Well logging]. Moscow, Nedra, 1982, $351 \mathrm{p}$.

21. Dobrynin V.M., Vendel'shtein B.Iu., Rezvanov R.A., Afrikian A.N. Promyslovaia geofizika [Field well logging]. Moscow, Nedra, 1986, 342 p.

22. D'iakonov D.I., Leont'ev E.I., Kuznetsov G.S. Obshchii kurs geofizicheskikh issledovanii skvazhin [General course of well logging]. Moscow, Nedra, 1984, 432 p.

23. Ellanskii M.M. Petrofizicheskie sviazi i kompleksnaia interpretatsiia dannykh promyslovoi geofiziki [Petrophysical links and integral interpretation of data from field geophysics]. Moscow, Nedra, $1978,215 \mathrm{p}$.

24. Dobrynin V.M. Geofizicheskie issledovaniia neftianykh i gazovykh skvazhin. Osnovnye problemy i trudnosti [Logging of oil and gas wells. Main challenges and difficulties]. Geofizika, 1993, no.1, pp.37-38.

25. Alger R.P., Harrison C.W. Improved fresh-water assessment in sand aquifers utilizing geophysical logs. Log Analyst, 1989, vol. 30, iss. 01, pp.31-44.

\section{Библиографический список}

1. Bertalanfi L. von. Allgemeine systemtheorie. Wege $\mathrm{zu}$ einer neuen mathesis universalis. - 1957. - Vol. 12, № 5/6. - P. 8-12.

2. Гудков Е.П., Косков В.Н. Системно-структурное моделирование нефтегазовых залежей по данным промыслово-геофизических исследований // Геология, геофизика и разработка нефтяных и газовых месторождений. - 1997. - № 12. - С. 21-24.

3. Дементьев Л.Ф. Системные исследования в нефтегазопромысловой геологии. - М.: Недра, 1988. - 204 с.

4. Кноринг Л.Д. Основы теории оптимизации разведки нефтяных месторождений. - Л.: Недра, 1980. - 304 c.

5. Косков В.Н. Интерпретация данных ГИС на базе системно-структурного подхода: учеб. пособие. Пермь: Изд-во Перм. нац. исслед. политехн. ун-та, 2012. - $140 \mathrm{c}$

6. Шурубор Ю.В. Системно-структурное моделирование разработки нефтяных и газовых месторождений (концептуальные основы; балансные, статистические и балансно-статистические методы, их алгоритмическое и программное обеспечение) / Перм. политехн. ин-т. - Пермь, 1991. - 42 с.

7. Urmantsev Yu.A. Symmetry of system and symmetry // Computers \& Mathematics with Applications. 1986. - Vol. 12, iss. 1-2, part B. - P. 379-405. DOI: $10.1016 / 0898-1221(86) 90160-4$

8. Вендельштейн Б.Ю., Резванов Р.А. Геофизические методы определения параметров нефтегазоносных коллекторов. - М.: Недра, 1978. - 318 с.

9. Геофизические методы изучения подсчетных параметров при определении запасов нефти и газа / Б.Ю. Вендельштейн, Г.М. Золоева, Н.В. Царева [и др.]. М.: Недра, 1985. - 248 с.

10. Косков В.Н., Косков Б.В. Геофизические исследования скважин и интерпретация данных ГИС: учеб. пособие. - Пермь: Изд-во Перм. гос. техн. ун-та, 2007. $-317 \mathrm{c}$ 
11. Горбачев Ю.И. Геофизические исследования скважин. - М.: Недра, 1990. - 398 с.

12. Ханин А.А. Петрофизика нефтяных и газовых пластов. - М.: Недра, 1976. - 295 с.

13. Griffiths I. Grain-size distribution and reservoirrock characteristics // Bulletin of the American Association of Petroleum Geologists. - 1952. - Vol. 36, № 2. - P. 205-229.

14. Pirson S.J. Handbook of well log analysis: for oil \& gas formation evaluation. - Prentice-hall, INK, Englewood Cliffs, N.J., 1963. - 414 p.

15. Tickell F.A., Hiatt W.N. Effect of angularity of grain on porosity and permeability of unconsolidated sands // Bulletin of the American Association of Petroleum Geologists. - 1938. - Vol. 22, № 9. - P. 1272-1274.

16. Дементьев Л.Ф., Акбашев Ф.С., Файнштейн В.М. Изучение свойств неоднородных терригенных нефтеносных пластов. - М.: Недра, 1980. - 213 с.

17. Стасенков В.В., Жданов А.С. Комплексное использование геолого-геофизических методов выделения нефтегазопродуктивных коллекторов. - М.: ВНИИОЭНГ, 1976. - 56 с.

18. Гусев В.М., Косков В.Н., Некрасов А.С. Оценка гранулометрического состава кварцевых песчаников по данным гамма-метода // Направления и методика поисково-разведочных работ в Пермском Прикамье / ИгиРГИ. - М., 1984. - С. 86-90.

19. Геофизические методы исследования нефтяных и газовых скважин / Л.И. Померанц, М.Т. Бондаренко, Ю.А. Гулин, В.Ф. Козяр. - М.: Недра, 1981. - 376 с.

20. Итенберг С.С., Дахкильгов Т.Д. Геофизические исследования в скважинах: учеб. для вузов. - М.: Недра, 1982. - 351 с.

21. Промысловая геофизика / В.М.Добрынин, Б.Ю. Вендельштейн, Р.А. Резванов, А.Н. Африкян. - М.: Недра, 1986. - 342 с.

22. Дьяконов Д.И., Леонтьев Е.И., Кузнецов Г.С. Общий курс геофизических исследований скважин. М.: Недра, 1984. - 432 с.

23. Элланский M.M. Петрофизические связи и комплексная интерпретация данных промысловой геофизики. - М.: Недра, 1978. - 215 с.

24. Добрынин В.М. Геофизические исследования нефтяных и газовых скважин. Основные проблемы и трудности // Геофизика. - 1993. - № 1. - С. 37-38.

25. Alger R.P., Harrison C.W. Improved fresh-water assessment in sand aquifers utilizing geophysical logs // Log Analyst. - 1989. - Vol. 30, iss. 01. - P. 31-44.

Please cite this article in English as:

Koskov V.N. Determination of lithologic belonging and reservoir properties of clastic formations using field geophysical survey data of Baklanovskoe field. Bulletin of PNRPU. Geology. Oil \& Gas Engineering \& Mining, 2017, vol.16, no.1, pp.4-13. DOI: $10.15593 / 2224-9923 / 2017.1 .1$

Просьба ссылаться на эту статью в русскоязычных источниках следующим образом:

Косков В.Н. Установление литологической принадлежности и коллекторских свойств терригенных пластов по промысловогеофизическим данным Баклановского месторождения // Вестник Пермского национального исследовательского политехнического университета. Геология. Нефтегазовое и горное дело. - 2017. - Т.16, №1. - C.4-13. DOI: 10.15593/2224-9923/2017.1.1 